\title{
Facile synthesis of luminescent carbon dots from mangosteen peel by pyrolysis method
}

\author{
Mahardika Prasetya Aji $^{1} \cdot$ Susanto $^{1} \cdot$ Pradita Ajeng Wiguna $^{1} \cdot$ Sulhadi $^{1}$
}

Received: 4 July 2016/ Accepted: 16 April 2017/Published online: 28 April 2017

(c) The Author(s) 2017. This article is an open access publication

\begin{abstract}
Carbon dots (C-Dots) from mangosteen peel has been synthesized by pyrolysis method. Synthesis of C-Dots is done using precursor solution which is prepared from extract of mangosteen peel as carbon source and urea as passivation agent. C-Dots is successfully formed with absorbance spectra at wavelength $350-550 \mathrm{~nm}$. Urea affects to the formed C-Dots, while the absorbance and the luminescent spectra are independent toward urea. C-Dots from extract of mangosteen peel has size in range $\sim 2-15 \mathrm{~nm}$. The absorbance peaks of C-Dots shows significant wavelength shift at visible region as the increasing of synthesized temperature. Shift of wavelength absorbance indicates the change of electronic transition of C-Dots. Meanwhile, the luminescent of C-Dots can be controlled by synthesized temperature as well. C-Dots luminescent were increasing as higher synthesized temperature. It was shown by the shift of wavelength emission into shorter wavelength, $465 \mathrm{~nm}$ at $200{ }^{\circ} \mathrm{C}, 450 \mathrm{~nm}$ at $250{ }^{\circ} \mathrm{C}$, and $423 \mathrm{~nm}$ at $300{ }^{\circ} \mathrm{C}$. Synthesized temperature also affects size of C-Dots. It has size $\sim 10-15 \mathrm{~nm}$ at $200{ }^{\circ} \mathrm{C}, \sim 7-11 \mathrm{~nm}$ at $250{ }^{\circ} \mathrm{C}$ and $\sim 2-4 \mathrm{~nm}$ at $300{ }^{\circ} \mathrm{C}$. In addition, temperature corresponds to the structure of carbon chains and $\mathrm{C}-\mathrm{N}$ configuration of formed $\mathrm{C}$-Dots from mangosteen peel extract.
\end{abstract}

Keywords Carbon dots $\cdot$ Mangosteen peel $\cdot$ Luminescent . Pyrolysis

Mahardika Prasetya Aji

mahardika190@gmail.com

1 Department of Physics, Universitas Negeri Semarang, Jalan Taman Siswa, Sekaran, Gunungpati, Semarang, Central Java 50229, Indonesia

\section{Introduction}

Carbon dots (C-Dots) have been attracted many researchers during last decade because of their fascinating luminescent properties, low toxicity, stability and chemical inertness $[1,2]$. C-Dots are new carbon nanomaterials with size below $10 \mathrm{~nm}$, first obtain during purification of single wall carbon nanotubes (SWNCTs) through electrophoresis in 2004 [3]. Small size and strong photoluminescent properties of C-Dots have shown great impact in various applications such as optoelectronic devices, photocatalyst, electrocatalyst and bioimaging [1, 4-10]. Moreover, C-Dots can be synthesized from natural carbon sources in low temperature that shows green, cheap and facile synthesis process.

Generally, synthesized processes of C-Dots can be classified into top-down and bottom-up process. Top-down method is based on cutting from a carbon source to form C-Dots particle, such as arch discharge, laser ablation and electrochemical oxidation [11-13]. Bottom-up method is using molecule precursors that are including polymerization of monomer, dehydration, and carbonization, as well as hydrothermal, pyrolysis, microwave, and supported synthesized [14-16]. Pyrolysis method is widely used as an effective one-step bottom-up method.

Nature provides unlimited carbon sources to engineer it as C-Dots materials. Several natural carbon sources that have been reported were orange, soybean, ginger, etc. $[14,15,17,18]$. Generally, carbon sources with abundant of carbon compound can be fabricated as C-Dots. One of interesting natural carbon source for C-Dots is mangosteen peel. Mangosteen (Garcinia mangostana L.) is a native fruit of Southeast Asia and widely grown in there [19]. The Mangosteen peel is known as source of anthocyanin pigment that commonly use as natural colorant and absorber 
material [19-21]. The pigment shows light absorption that corresponds to the electronic transition, but it cannot produce electron and hole since the absence of photoluminescent in the pigment. Therefore, synthesis of C-Dots from mangosteen peel gives a chance to reveal luminescent mechanism of C-Dots while it's mechanism still lacking.

\section{Experiment}

Synthesis of C-Dots from mangosteen peel was used pyrolysis method. Five-teen gram of mangosteen peel was heated in $100 \mathrm{ml}$ distilled water at $70{ }^{\circ} \mathrm{C}$. The result solution showed yellow-brown color and then $20 \mathrm{ml}$ of the solution added by urea as precursor solution. The precursor solution is heated in the furnace along $30 \mathrm{~min}$ for forming C-Dots. The Influence of urea and heating temperature were proposed to study the properties of C-Dots. The urea, 1-6 $\mathrm{g}$ was used in precursor solution while the synthesized temperature was $200{ }^{\circ} \mathrm{C}$. To study the influence of temperature on C-Dots properties, the synthesized temperature was conducted in 200,250 and $300{ }^{\circ} \mathrm{C}$.

The characterization of C-Dots absorbance was used spectrophotometer VIS-NIR Ocean Optics type USB 4000. The energy gap of C-Dots was determined by Tauc plot method form absorbance spectra, using following equation:

$\alpha^{2}=\frac{h c}{\lambda}-E_{\mathrm{g}}$

while $\alpha$ is an absorption coefficient $\left(m^{-1}\right), h$ is Planck constant $\left(4136 \times 10^{-15} \mathrm{eV} \mathrm{s}\right), \lambda$ is wavelength $(m)$ and $E_{\mathrm{g}}$ is energy gap of C-Dots. The photoluminescent of C-Dots was characterized by spectrophotometer photoluminescent Cary Eclipse Spectroflourometer MY14440002 with wavelength excitation $365 \mathrm{~nm}$. Structure of C-Dots was investigated by FTIR spectra using FTIR spectrophotometer Perkin Elmer Spectrum Version 10.03.06. Transmission electron microscope images were taken by JEOL JEM-1400 electron microscope. Meanwhile, element compositions were investigated SEM-EDX using Phenom Pro X Desktop electron microscope.

\section{Result and discussion}

The absorbance spectra of C-Dots shows that the absorption region of C-Dots around $350-550 \mathrm{~nm}$. The main absorptions are at $369 \mathrm{~nm}$ and $405-415 \mathrm{~nm}$. The absorptions show main characteristic of $\pi$ electron transition [19]. The absorbance spectra of C-Dots which depend on various amount of urea are shown in Fig. 1. There are no significant absorption wavelength shifts when the adjusting amount of urea that indicate no significant change of the structure. The peak absorption tends to increase as the adjusting urea till $2 \mathrm{~g}$ and decreases as higher of urea. It may correspond to the number of formed C-Dots.

The absorbance spectra of C-Dots in various temperatures can be shown in Fig. 2. The absorbance peaks of C-Dots shows significant wavelength shift at visible region as increasing synthesized temperature. The absorption peaks are $412 \mathrm{~nm}$ at $200{ }^{\circ} \mathrm{C}, 429 \mathrm{~nm}$ at $250{ }^{\circ} \mathrm{C}$ and $389 \mathrm{~nm}$ at $300{ }^{\circ} \mathrm{C}$. Shift of wavelength absorption indicated to change of electronic transition in C-Dots. Absorption at region $350-500 \mathrm{~nm}$ in C-Dots are corresponds to $\pi-\pi^{*}$ electron transition [22, 23].

Electronic transition of C-Dots occurred in HOMO as minimum level energy to LUMO as the higher level energy

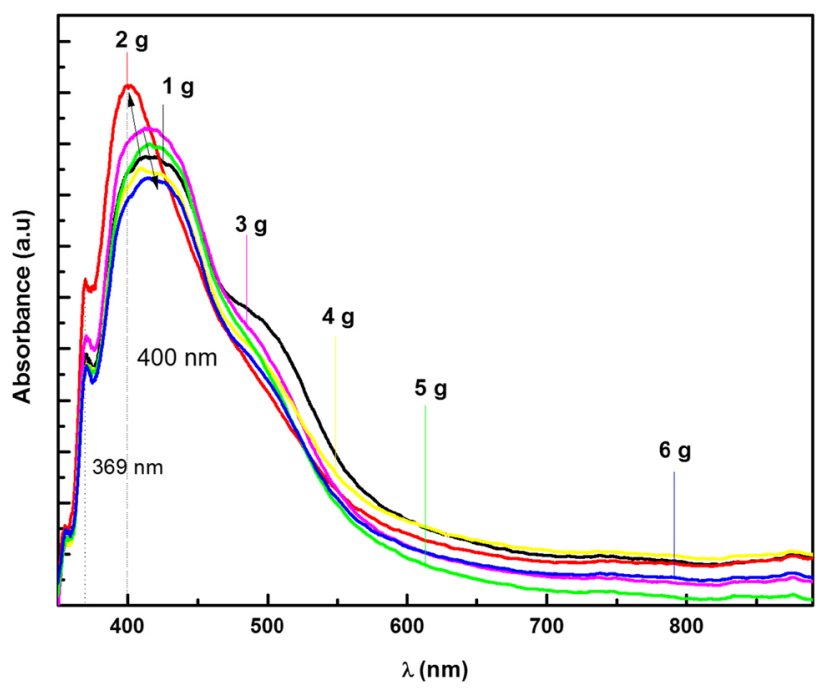

Fig. 1 Absorbance spectra C-Dots in various amount of urea 1-6 g

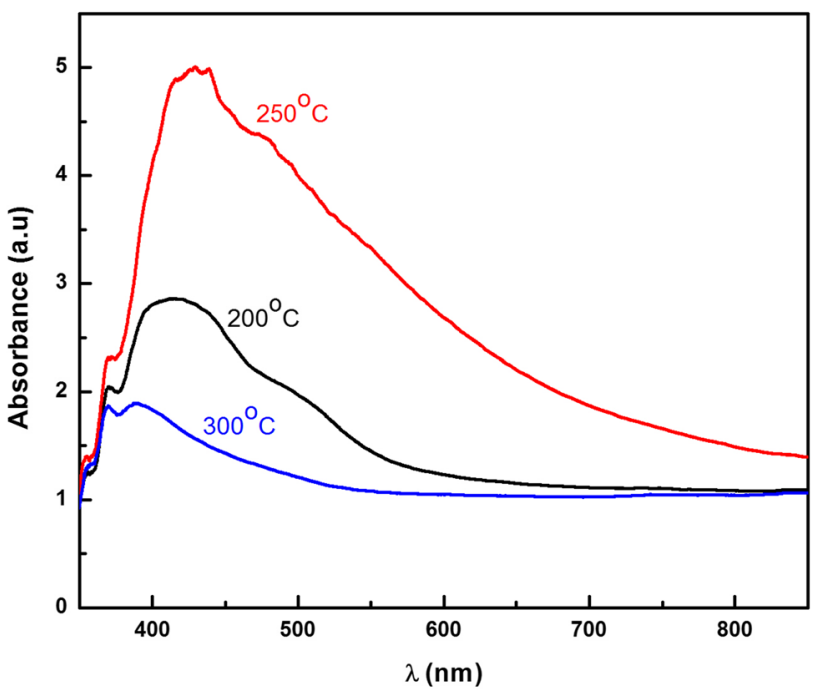

Fig. 2 Absorbance spectra C-Dots in temperature 200, 250 and $300{ }^{\circ} \mathrm{C}$ 
[22]. To electron transition is occurred, the minimum energy must be provided. Hence, structure of C-Dots energy gap probably to be controlled by heating temperature. Energy gap of C-Dots has been determined by Tauc plot method.

The energy gap in urea variations are shown in Fig. 3. The energy gap of C-Dots were $\sim 2.1 \mathrm{eV}$, which independent on urea concentration. Electronic structure of C-Dots and their size unchanged under the various urea concentrations. Urea plays the important role on the amount of formed C-Dots which correspond to the absorbance spectra pattern.

Energy gap of C-Dots in various synthesized temperature shown in Fig. 4. The energy gap were $\sim 2.1 \mathrm{eV}$ at $200{ }^{\circ} \mathrm{C}, \sim 1.9 \mathrm{eV}$ at $250{ }^{\circ} \mathrm{C}$, and $\sim 2.74 \mathrm{eV}$ at $300{ }^{\circ} \mathrm{C}$. The energy gap changed under variation of heating temperature corresponded to change of C-Dots size. Size of C-Dots are estimated by TEM image shown in Fig. 5. Size of C-Dots
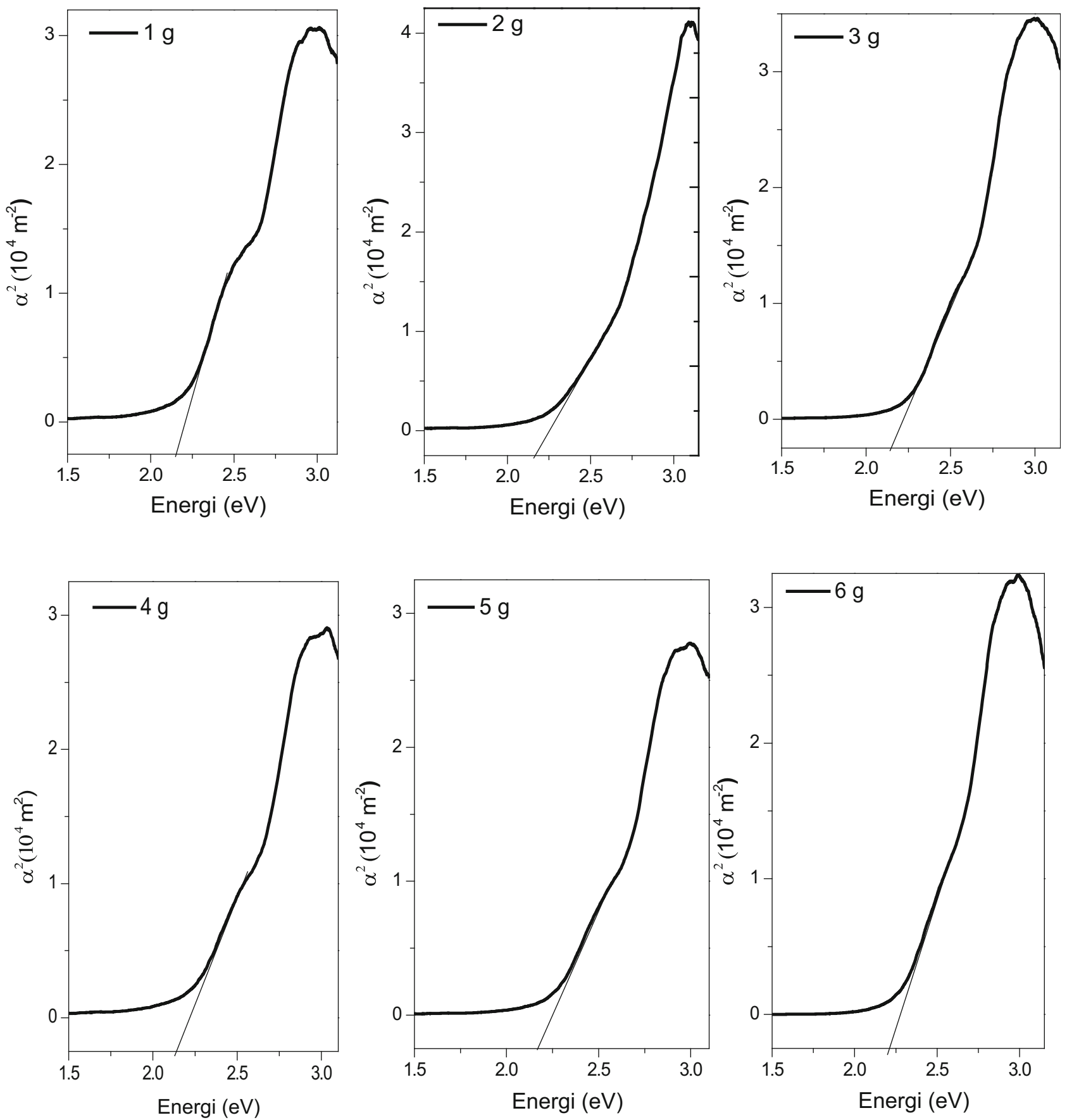

Fig. 3 Energy gap of C-Dots from mangosteen peel in various urea 1-6 g 

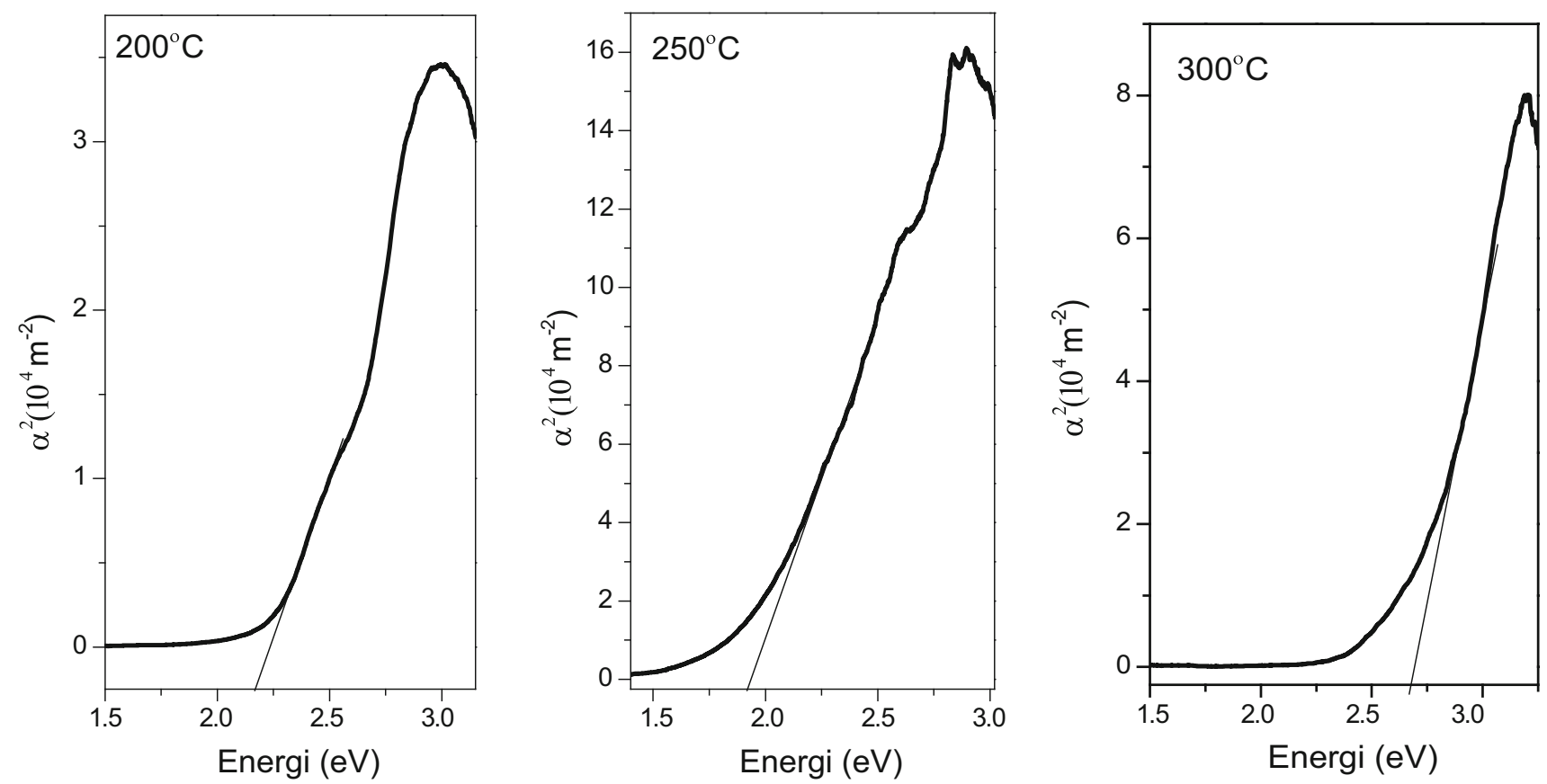

Fig. 4 Energy gap of C-Dots from mangosteen peel in temperature 200, 250 and $300{ }^{\circ} \mathrm{C}$

from mangosteen peel extract are $\sim 10-15 \mathrm{~nm}$ at $200{ }^{\circ} \mathrm{C}$, $\sim 7-11 \mathrm{~nm}$ at $250{ }^{\circ} \mathrm{C}$ and $\sim 2-4 \mathrm{~nm}$ at $300{ }^{\circ} \mathrm{C}$. The higher thermal energy provides the higher energy in polymerization and carbonization processes of C-Dots particle formation that affect to C-Dots size. Small size of C-Dots leads to emerging of quantum confinement effect. Therefore, reducing particle size leads to wider energy gap.

An interesting phenomenon was obtained in this research. Both of C-Dots and mangosteen peel had absorbance around $350-550 \mathrm{~nm}$, but only C-Dots exhibited luminescent properties as shown in Fig. 6. It means that C-Dots and mangosteen peel can absorb photon energy in the $\pi$ orbital. Photon energy in mangosteen peel probably use to dynamic molecular motion or polarize all molecules. Therefore mangosteen peel has no PL property. Otherwise, after pyrolysis treatment $\mathrm{C}$-Dots were formed. The change of electronic structure clearly confirmed that there was gap structure formation in C-Dots. In addition, it leads to radiative transition when photon absorbed by C-Dots. Therefore, C-Dots have PL properties.

Photoluminescence spectra of C-Dots with urea variations under the excitation wavelength at $365 \mathrm{~nm}$ were shown in Fig. 7. Increasing the amount of urea are unchanged the wavelength emission of C-Dots. The PL intensity of C-Dots increases up to $2 \mathrm{~g}$ and decreases gradually while the amount of urea is increasing. That indicates the number of C-Dots can be controlled by the amount of urea. As higher the number of C-Dots which are formed, it will emit higher photon intensity and causes PL intensity sharper. In addition, it corresponds to the unchanged electronic structure in energy gap of C-Dots. Figure 7 shows the maximum emission of synthesized C-Dots with the urea variation at $465 \mathrm{~nm}$.

The mechanism of C-Dots photoluminescent is including radiative electronic transition in $\pi$ orbital. Electrons in HOMO orbital are excited to LUMO orbital when the energy is absorbed by C-Dots as illustrated in Fig. 8. The electrons in LUMO state are unstable and relaxed to HOMO state while radiate visible photon energy.

Temperatures effect on photoluminescent C-Dots shown in Fig. 9. The wavelength emissions of C-Dots are $465 \mathrm{~nm}$ $(2.67 \mathrm{eV})$ at $200{ }^{\circ} \mathrm{C}, 450 \mathrm{~nm}(2.76 \mathrm{eV})$ at $250{ }^{\circ} \mathrm{C}$, and $423 \mathrm{~nm}(2.93 \mathrm{eV})$ at $300{ }^{\circ} \mathrm{C}$. Emission energy of C-Dots increase as increasing of synthesized temperature, while the emission shifts into shorter wavelength. The energy emission of C-Dots corresponds to particle size of C-Dots that have been formed. Li et al. 2010 have approximated using density functional theory that the higher emission energy relate to smaller particle size of C-Dots [18]. Small size of C-Dots which less than $10 \mathrm{~nm}$ in diameter can be understood by dots particle behaviors. As low dimensional particle, dots particle undergo quantum confinement effect. The quantum confinement effect revealed that as reducing size of dots particle the energy level would be completely quantized, increase and split into wider level. It cause numbers of possibility transition energy in dots particle which increase and occurs in higher energy as the size is reduced. Therefore, the emission energy of C-Dots which increase corresponds to the reducing of the size particles that have been formed. 

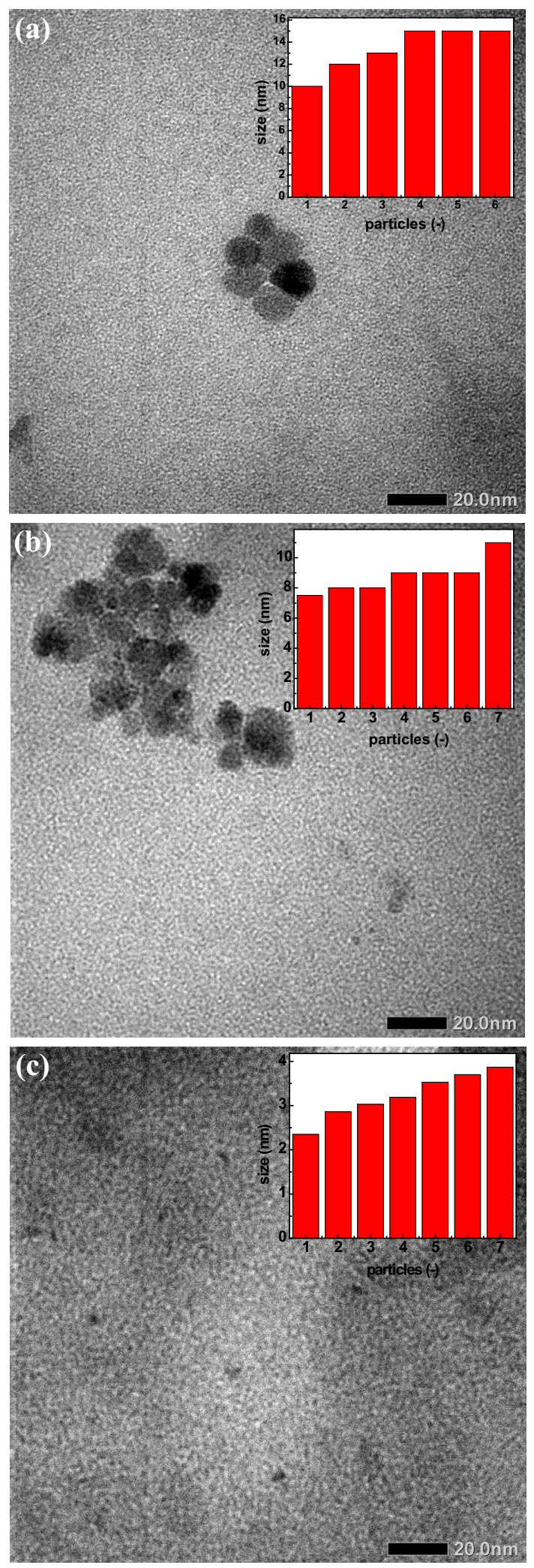

Fig. 5 TEM images of C-Dots which are synthesized at temperature : a $200{ }^{\circ} \mathrm{C}$, b $250{ }^{\circ} \mathrm{C}$ and c $300{ }^{\circ} \mathrm{C}$

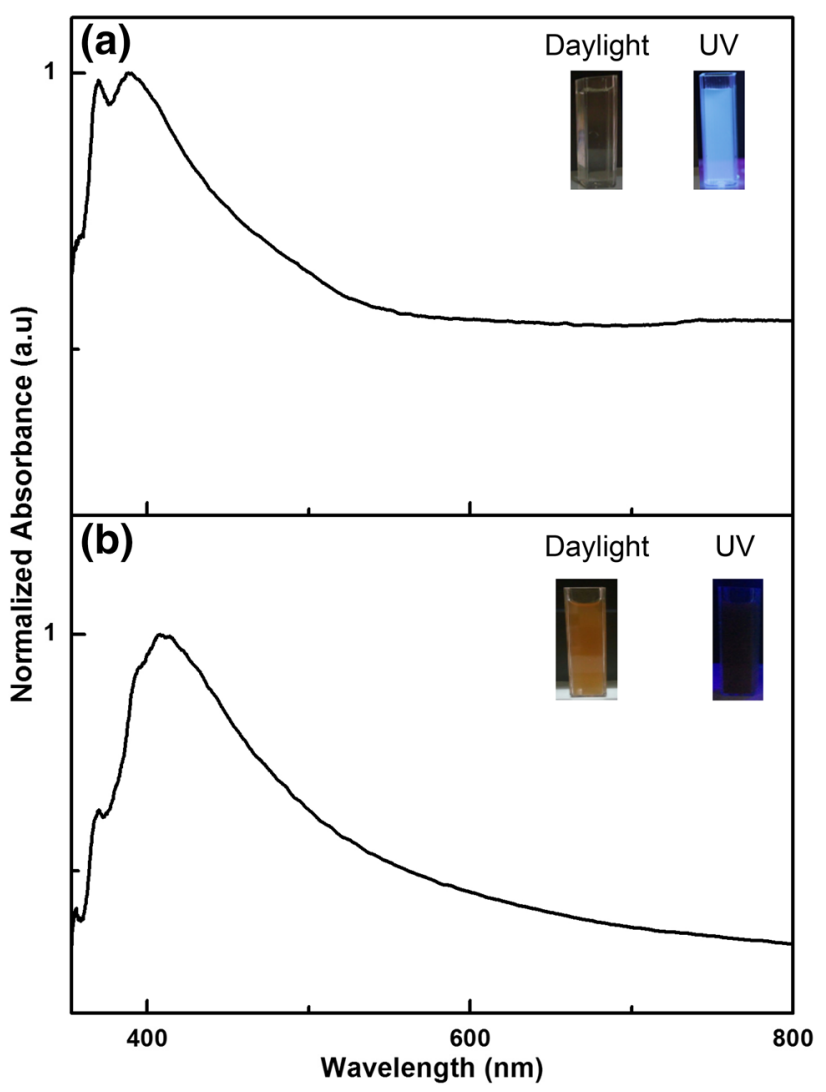

Fig. 6 Absorbance spectra and photograph of a C-Dots, b mangosteen peel

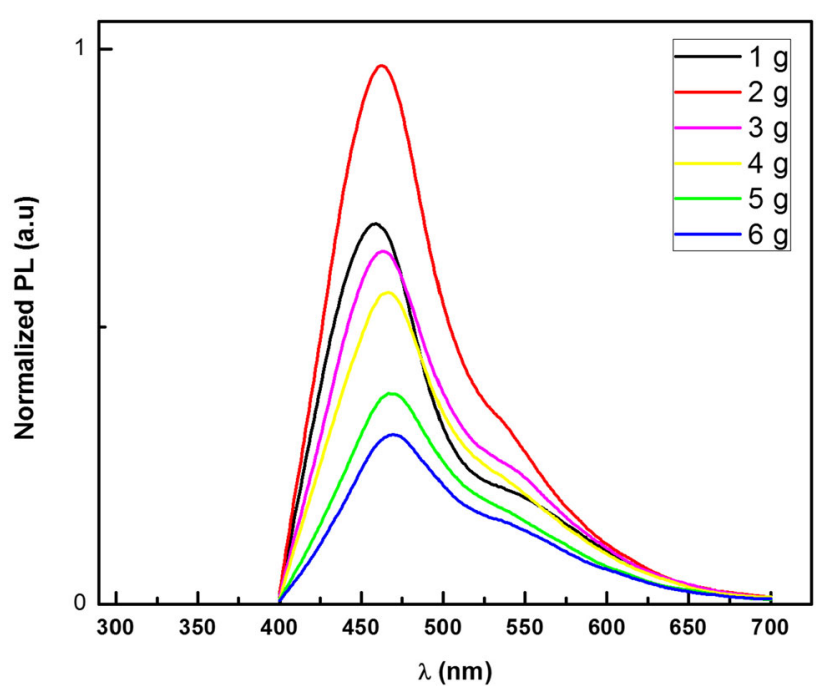

Fig. 7 Photoluminescent spectra of synthesized C-Dots with various urea 1-6 g under excitation wavelength $365 \mathrm{~nm}$ 


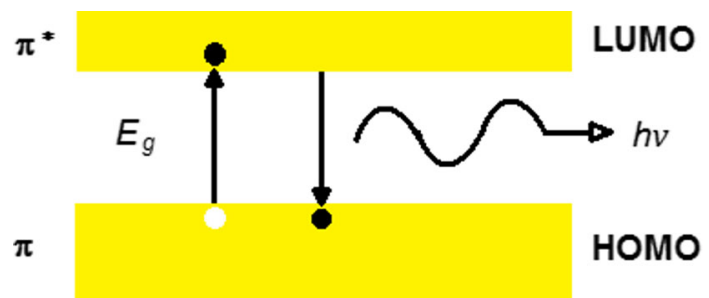

Fig. 8 Illustration of mechanism photoluminescent C-Dots from mangosteen peel

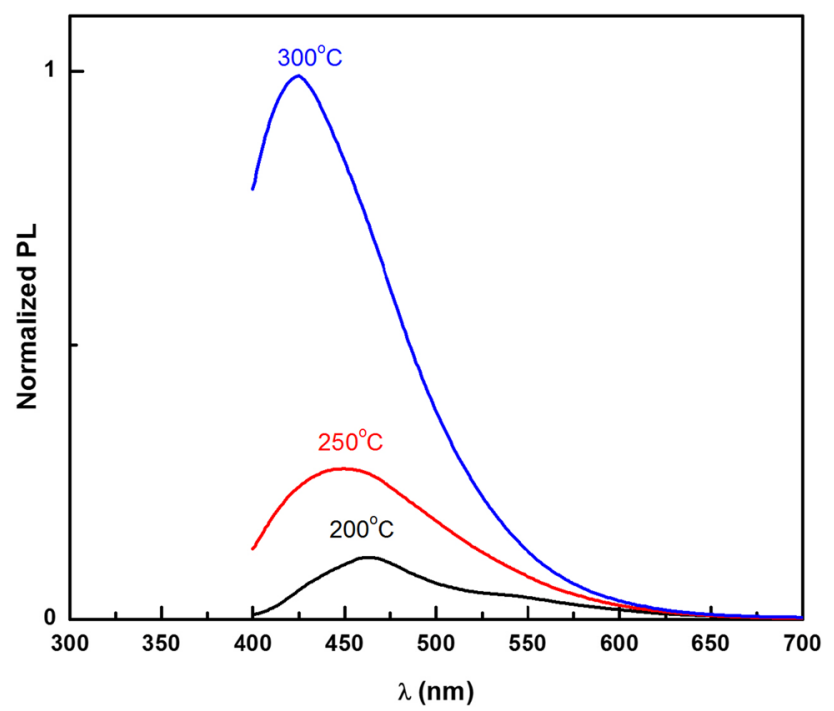

Fig. 9 Photoluminescent spectra of synthesized C-Dots in temperature 200, 250 and $300{ }^{\circ} \mathrm{C}$ under excitation wavelength $365 \mathrm{~nm}$
The result of element analysis using SEM-EDX shows that C-Dots contains dominant elements as C (32.7\%), N $(48.1 \%)$ and $\mathrm{O}(19.2 \%)$. The structure of C-Dots from mangosteen peel has been characterized by FTIR. The result of characterization is shown in Fig. 10. The result shows that spectra of mangosteen peels and C-Dots are different. The mangosteen peels has sharp peak at 3462, 1634 and $675 \mathrm{~cm}^{-1}$. It corresponds to $\mathrm{OH}$ stretching, $\mathrm{C}=\mathrm{C}$ aromatic stretching and $\mathrm{OH}$ bending [24]. The mangosteen peels structure change into C-Dots by deformation of ring structure and nitrogen chain formation. It was shown in the appearance of new peaks at $1700-1000 \mathrm{~cm}^{-1}$ in the C-Dots spectra. Heating treatment and urea lead to deformation of mangosteen peel structure and form C-Dots.

According to the FTIR result, synthesized C-Dots from mangosteen peel at $200{ }^{\circ} \mathrm{C}$ shows band peaks at 3459 , $3362 \mathrm{~cm}^{-1}$ that assign stretching $\mathrm{OH}$ (hydroxyl and carboxylate group), stretching $\mathrm{N}-\mathrm{H}$ (amine group) [25, 26]. The FTIR result also display sharp peaks at 1670, 1624, and $1456 \mathrm{~cm}^{-1}$ which correspond to stretching $\mathrm{C}=\mathrm{O}$ (ketone group), stretching $\mathrm{C}=\mathrm{C}$, and deformation $\mathrm{C}-\mathrm{H}$ (methyl group) for synthesized C-Dots at $200{ }^{\circ} \mathrm{C}[13,27]$. Synthesized C-Dots at $250{ }^{\circ} \mathrm{C}$ shows stretching $\mathrm{OH}$ $\left(3454 \mathrm{~cm}^{-1}\right)$, stretching $\mathrm{N}-\mathrm{H}\left(3362 \mathrm{~cm}^{-1}\right)$, stretching $\mathrm{C}=\mathrm{O}$ $\left(1670 \mathrm{~cm}^{-1}\right)$, deformation C-H $\left(1456 \mathrm{~cm}^{-1}\right)$, that confirms carboxylate, hydroxyl, amine, ketone and methyl group in surface ligands of $\mathrm{C}$-Dots $[1,3,12]$. The appearance of stretching $\mathrm{C}=\mathrm{C}$ peak at $1624 \mathrm{~cm}^{-1}$ corresponds to ring structure of C-Dots core for graphite structure since C-Dots
Fig. 10 FTIR spectra of mangosteen peel extract and synthesized C-Dots at temperature 200, 250 and $300{ }^{\circ} \mathrm{C}$

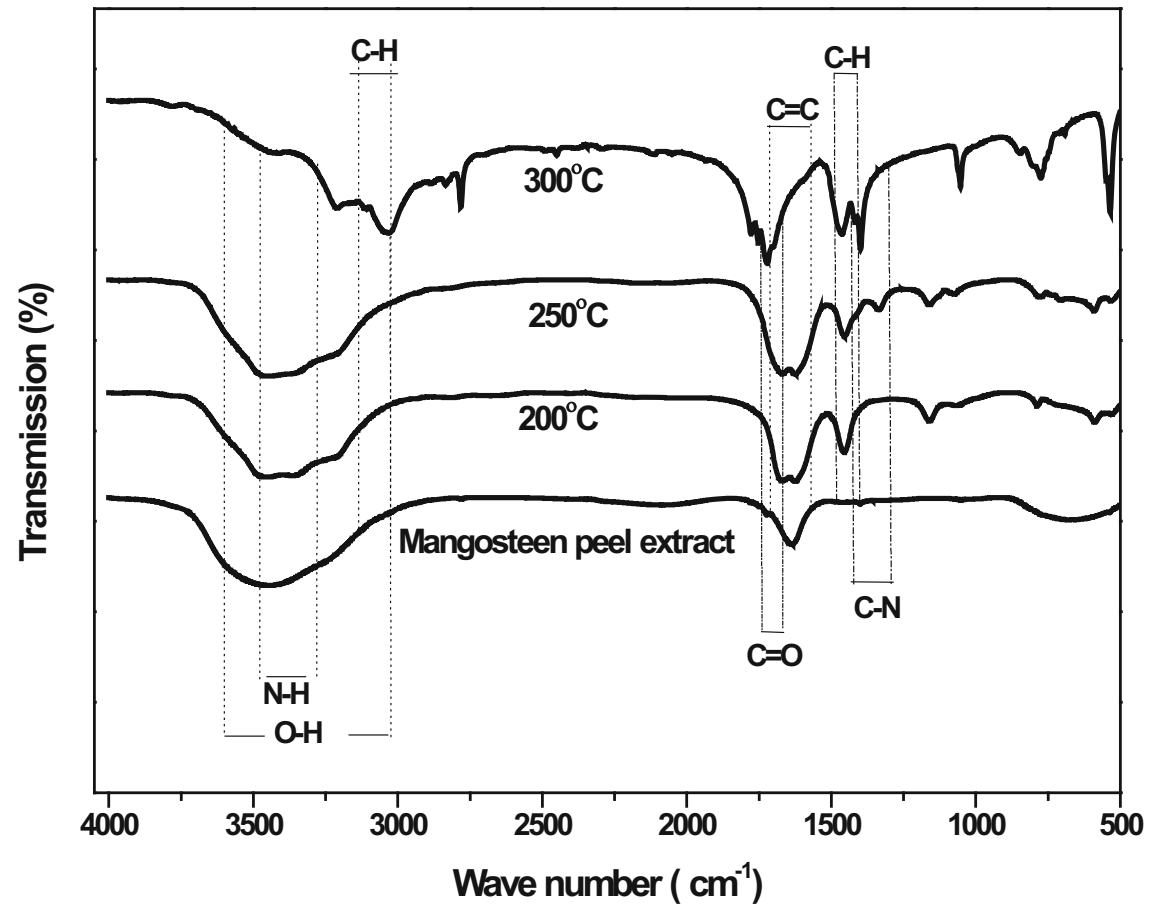


is consist of core and ligand molecule [3, 28]. C-N configuration was appears at $1334 \mathrm{~cm}^{-1}$ in synthesized C-Dots at $250{ }^{\circ} \mathrm{C}$ shows nitrogen containing from urea successfully modify C-Dots structure $[25,27,29]$. As the results in synthesized C-Dots at 200 and $250{ }^{\circ} \mathrm{C}$, synthesized C-Dots at $300{ }^{\circ} \mathrm{C}$ the detection peaks at $3208,1721,1456 \mathrm{~cm}^{-1}$ are relate to $\mathrm{OH}$ stretching (hydroxyl group) and $\mathrm{C}=\mathrm{O}$ stretching (carboxyl group) and deformation $\mathrm{C}-\mathrm{H}$ (methyl group) which indicate surface ligands of C-Dots, while aromatic structure of $\mathrm{C}-\mathrm{H}$ stretching $\left(3034 \mathrm{~cm}^{-1}\right)$ indicate graphitic structure in C-Dots core.

C-N configuration also appears in the synthesized $\mathrm{C}$-Dots at $300{ }^{\circ} \mathrm{C}$. The peak detection is sharper than the synthesized C-Dots at $250{ }^{\circ} \mathrm{C}$ which is shown at $1339 \mathrm{~cm}^{-1}$. The $\mathrm{C}-\mathrm{N}$ configuration plays an important role on PL of C-Dots. Nitrogen dopes graphitic structure in the core of C-Dots that presence $\mathrm{C}-\mathrm{N}$ bonding. The presence of $\mathrm{C}-\mathrm{N}$ bounding creates emission energy trap that increase radiative recombination induced by the electron-hole pairs [27]. Due to the increasing radiative recombination in C-Dots, the numbers of photons emission are increasing as well. So that it leads to the higher of PL intensity.

\section{Conclusion}

C-Dots from mangosteen peel have been synthesized using pyrolysis method. The result shows number of formed C-Dots can be controlled by the urea concentration. However, the synthesized temperature affects to the electronic transition and PL properties of C-Dots. Luminescent of C-Dots increases as the higher of synthesized temperature, which corresponds to the shift of wavelength emission into shorter wavelength. Furthermore, the synthesized temperature leads to form $\mathrm{C}-\mathrm{N}$ configuration of C-Dots that plays an important role on the structure and luminescent energy as well.

Acknowledgement We are very thankful to Jotti Karunawan, Annisa Lidia Wati, Aan Priyanto, Ita Rahmawati, and Nila Fitriya for helping in discussion, sample preparation and TEM analysis.

Open Access This article is distributed under the terms of the Creative Commons Attribution 4.0 International License (http://crea tivecommons.org/licenses/by/4.0/), which permits unrestricted use, distribution, and reproduction in any medium, provided you give appropriate credit to the original author(s) and the source, provide a link to the Creative Commons license, and indicate if changes were made.

\section{References}

1. Li, H., Kang, Z., Liu, Y., Lee, S.T.: Carbon nanodots: synthesis, properties and applications. J. Mater. Chem. 22, 24230-24253 (2012)
2. Ray, S.C., Saha, A., Jana, N.R., Sarkar, R.: Fluorescent carbon nanoparticles: synthesis, characterization, and bioimaging application. J. Phys. Chem. C 113, 18546-18551 (2009)

3. Baker, S.N., Baker, G.A.: Luminescent carbon nanodots: emergent nanolight. Angew. Chem. Int. Ed. 49, 6726-6744 (2010)

4. Aji, M.P., Wiguna, P.A., Susanto., Wicaksono, R., Sulhadi.: Identification of carbon dots in waste cooking oil. Adv. Mater. Res. 1123, 402-405 (2015)

5. Huang, J.J., Zhong, Z.F., Rong, M.Z., Zhou, X., Chen, X.D., Zhang, M.Q.: An easy approach of preparing strongly luminescent carbon dots and their polymer based composites for enhancing solar cell effiency. Carbon 70, 190-198 (2014)

6. Park, S.Y., Lee, H.U., Park, E.S., Lee, S.C., Lee, J.W., Jeong, S.W., Kim, C.H., Lee, Y.C., Huh, Y.S., Lee, J.: Photoluminescent green carbon nanodots from food-waste-derived sources: largescale synthesis, properties, and biomedical applications. ACS Appl. Mater. Interfaces. 6, 3365-3370 (2014)

7. Aji, M.P., Wiguna, P.A., Suciningtyas, S.A., Susanto., Rosita, N., Sulhadi.: Carbon nanodots from frying oil as catalyst for photocatalytic degradation of methylene blue assisted solar light irradiation. Am. J. of Appli. Sci. 13, 432-438 (2016)

8. Aji, M.P., Wiguna, P.A., Susanto., Rosita, N., Suciningtyas, S.A., Sulhadi.: Performance of photocatalyst based carbon nanodots from waste frying oil in water purification. AIP Conf. Proc. 1725, 020001-1-020001-6 (2016)

9. Wang, J., Gao, M., Ho, G.W.: Bidentate-complex-derived $\mathrm{TiO}_{2}$ /carbon dot photocatalysts: in situ synthesis, versatile heterostructures, and enhanced $\mathrm{H}_{2}$ evolution. J. Mater. Chem. A 2, 5703-5709 (2014)

10. Wang, J., Lim, Y.F., Ho, G.W.: Carbon-ensemble-manipulated $\mathrm{ZnS}$ heterostructures for enhanced photocatalytic $\mathrm{H}_{2}$ evolution. Nanoscale 6, 9673-9680 (2014)

11. Xu, X., Ray, R., Gu, Y., Ploehn, H.J., Gearheart, L., Raker, K., Scrivens, W.A.: Electrophoretic analysis and purification of fluorescent single-walled carbon nanotube fragments. J. Am. Chem. Soc. 126, 12736-12737 (2004)

12. Hu, S.L., Niu, K.Y., Sun, J., Yang, J., Zhao, N.Q., Du, X.W.: One-step synthesis of fluorescent carbon nanoparticles by laser irradiation. J. Mater. Chem. 19, 484-488 (2009)

13. Li, H., He, X., Kang, Z., Huang, H., Liu, Y., Liu, J., Lian, S., Tsang, C.H.A., Yang, X., Lee, S.T.: Water-soluble fluorescent carbon quantum dots and photocatalyst design. Angew. Chem. Int. Ed. 49, 4430-4434 (2010)

14. Sahu, S., Behera, B., Maiti, T.K., Mohapatra, S.: Simple one-step synthesis of highly luminescent carbon dots from orange juice: application as excellent bio-imaging agents. Chem. Commun. 48, 8835-8837 (2012)

15. Zhu, H., Wang, X., Li, Y., Wang, Z., Yang, F., Yang, X.: Microwave synthesis of fluorescent carbon nanoparticles with electrochemi luminescence properties. Chem. Commun. 34, 5518-5520 (2009)

16. Zhong, J., Zhu, Y., Yang, X., Shen, J., Li, C.: Synthesis of photoluminescent carbogenic dots using mesoporous silica spheres as nanoreactors. Chem. Commun. 47, 764-766 (2011)

17. Wang, J., Ng, Y.H., Lim, Y.F., Ho, G.W.: Vegetable-extracted carbon dots and their nanocomposites for enhanced photocatalytic $\mathrm{H}_{2}$ production. RSC Adv. 4, 44117-44123 (2014)

18. Li, C.L., Ou, C.M., Huang, C.C., Wu, W.C., Chen, Y.P., Lin, T.E., Ho, L.C., Wang, C.W., Shih, C.C., Zhou, H.C., Lee, Y.C., Tzeng, W.F., Chiou, T.J., Chu, S.T., Cang, J., Chang, H.T.: Carbon dots prepared from ginger exhibiting efficient inhibition of human hepatocellularcar cinoma cells. J. Matter. Chem. B. 2, 4564-4571 (2014)

19. Chiste, R.C., Lopes, A.S., de Faria, L.J.G.: Thermal and light degradation kinetics of anthocyanin extracts from mangosteen peel (Garcinia mangostana L.). Int. J. Food Sci. Tech. 45, 1902-1908 (2010) 
20. Maiaugree, W., Lowpa, S., Towannang, M., Rutphonsan, P., Tangtrakarn, A., Pimanpang, S., Maiaugree, P., Ratchapolthavisin, N., Sang-aroon, W., Jarernboon, W., Amornkitbamrung, V.: A dye sensitized solar cell using natural counter electrode and natural dye derived from mangosteen peel waste. Sci. Rep. 5, 1-12 (2015)

21. Chien, C.Y., Hsu, B.D.: Performance enhancement of dye-sensitized solar cells based on anthocyanin by carbohydrates. Sol. Energy 108, 403-411 (2014)

22. Qu, S., Wang, X., Lu, Q., Liu, X., Wang, L.: A biocompatible fluorescent ink based on water-soluble luminescent carbon nanodots. Angew. Chem. Int. Ed. 124, 12381-12384 (2012)

23. Niu, J., Gao, H., Wang, L., Xin, S., Zhang, G.Y., Wang, Q., Guo, L., Liu, W., Gao, X., Wang, Y.: Facile synthesis and optical properties of nitrogen-doped carbon dots. New J. Chem. 38, 1522-1527 (2014)

24. Munawaroh, H., Fadilah, G., Saputri, L.N.M.Z., Hanif, Q.A., Hidayat, R., Wahyuningsih, S.: c (Garcinia mangostana L.) as natural dye for dye-sensitized solar cells (DSSC). IOP Conf. Series. Mater. Sci. Eng. 107, 1-6 (2016)

25. Dey, S., Chithaiah, P., Belawadi, S., Biswas, K., Rao, C.N.R.: New methods of synthesis and varied properties of carbon quantum dots with high nitrogen content. J. Mater. Res. 29, 383-391 (2014)

26. Rahmayanti, H.D., Sulhadi., Aji, M.P.: Synthesis of sulfur-doped carbon dots by simple heating method. Adv. Mater. Res. 1123, 233-236 (2015)

27. Xu, Y., Wu, M., Liu, Y., Feng, X.X., Yin, X.B., He, X.W., Zhang, Y.K.: Nitrogen-doped carbon dots: a facile and general preparation method, photoluminescence investigation and imaging cell application. Chem. Eur. J. 19, 2276-2283 (2013)

28. Georgakilas, V., Perman, J.A., Tucek, J., Zboril, R.: Broad family of carbon nanoallotropes: classification, chemistry and applications of fullerenes, carbon dots, nanotubes, graphene, nanodiamonds and combined superstructures. Chem. Rev. 115, 4744-4822 (2015)

29. Liu, N., Liu, J., Kong, W., Li, H., Huang, H., Liu, Y., Kang, Z.: One-step catalase controllable degradation of $\mathrm{C}_{3} \mathrm{~N}_{4}$ for $\mathrm{N}$-doped carbon dots green fabrication and their bioimaging applications. J. Mater. Chem. B 2, 5768-5774 (2014) 